\title{
INTRODUCED SPECIES COMMUNITY OVER-DOMINATES ENDEMIC ICHTHYOFAUNA OF HIGH LIKA PLATEAU (CENTRAL CROATIA) OVER A 100 YEAR PERIOD
}

\author{
Dušan Jelić ${ }^{1,2}$, Ivan Špelić ${ }^{3}$ and Petar Žutinić ${ }^{4}$ \\ ${ }^{1}$ Croatian Institute for Biodiversity, Croatian Herpetological Society Hyla, Zagreb, Croatia \\ Lipovac I, 7, 10000 Zagreb, Croatia; E-mail: jelic.dusan@gmail.com \\ ${ }^{2}$ Institute for Research and Development of Sustainable Ecosystems \\ Jagodno 100a. 10410 Velika Gorica, Croatia \\ ${ }^{3}$ Croatian Institute for Biodiversity, Croatian Society for Biological Research \\ Lipovac I, 7, 10000 Zagreb, Croatia; E-mail: ivanspelic@gmail.com \\ ${ }^{4}$ University of Zagreb, Faculty of Science, Department of Biology \\ Rooseveltov trg 6, 10000 Zagreb, Croatia; E-mail: petar.zutinic@gmail.com
}

108 years after TRGovčić (1908) authors made a revised list of fish species found in rivers and streams of the Lika region. Throughout the 8 years of investigation a total of 31 species of freshwater fish were recorded, of which only eight are indigenous for this area, for two species the origin is not known, and the remaining 21 species are introduced by anthropogenic activity over the last 100 years. This represents the over-domination of introduced species by the astonishing $300 \%$. All of this increase in numbers causes significant increase in biomass and changes the naturally oligotrophic ecosystem, which might lead to rapid eutrophication and increase of water temperature. Furthermore, induced changes in the system make the habitat more suitable for introduced cyprinid fish, which again causes the increase of biomass production. Endemic fish species are retreating into upper parts of small tributaries and underground cave systems. The present research indicates species Delminichthys jadovensis, D. krbavensis, Telestes fontinalis and T. croaticus as real stygophiles, which makes them unique on the European continent.

Key words: ichthyofauna, Lika region, Croatia, fish, distribution, stygophiles

\section{INTRODUCTION}

An "introduced", "non-indigenous", "alien" or "non-native" species is a species living outside its native distributional range due to either deliberate or accidental human activity (PetTorelli 2013), and succeed in surviving and subsequently reproducing. The European Union defines "Invasive Alien Species" as species outside their natural distribution area whose introduction and/or spread threaten biological diversity (COMMISsion of the EUROPEAN Communities 2008). They represent one of the biggest threats to biodiversity in present times, and discussions about their impact on the world economy are increasing (Copp et al. 2005). Ecological impacts of invasive alien species (RICCIARDi $e t$ al. 2013) include predation, competition and hybridization with native species and general alterations of ecosystems (Rodriguez 2006), all of 
which lead to invasive alien species being the second largest cause of biodiversity loss (McNeely et al. 2001). Alien species can cause modifications of habitats (Grarock et al. 2014) because they did not evolve with those habitats (SCHLAepfer et al. 2005) and they effect distribution, abundance and reproduction of many native species (Strauss et al. 2006). A very high percentage of invasive fish species has been recorded in recent publications on distribution of freshwater fish in Croatian rivers, like Ilova, Cesma, Drava and Zrmanja Rivers (Mrakovčić et al. 2006, Dumbović et al. 2009, Jelić et al. 2009, 2010, 2012, Miočić-Sтоšić et al. 2012). Contrary, a sparseness of data on native fish species in the Mediterranean region with very narrow (Žutinić et al. 2014) or endemic distribution (SMith \& DaRWALl 2006) highlights a need to urgently intensify both conservation actions (Jones \& Oliver 2009) and ecological research.

In terms of ichthyology, Lika plateau is one of the most interesting parts of Croatia and Western Balkans, due to high number of endemic species. Despite its attractiveness, the whole area is poorly explored (MraKovčić et al. 1995). Franz Steindachner (1866), Austrian ichthyologist and curator at the Vienna Natural History Museum, was the first who pointed out the potential abundance of endemic species of the region. By examining museum samples from the area he described endemic Croatian minnow, naming it Paraphoxinus croaticus (valid name is Telestes croaticus Steindachner, 1866). From the list of fish species preserved in the Public Zoological Museum in Zagreb, LanghofFER (1905) recorded T. croaticus and Anguilla anguilla (Linnaeus, 1758) for River Lika, and probably T. fontinalis (Karaman, 1972) for Krbavsko polje (even though he named it Paraphoxinus croaticus). Trgovčević $(1905,1908,1932)$ lists eight species for the whole Lika region and claims that "Paraphoxinus croaticus Steindachner" is the most abundant species in Lika streams, because "wherever it lives, and that is in almost every stream... It just thrives, other species are far less represented, and they also live in some streams with no other species found (like Paraphoxinus adspersus in Balatin stream)...". Poljak (1924) records P. croaticus (T. croaticus) in Ljubica stream near Baške Oštarije. Review of more recent studies shows that Haвекоvić et al. (1992) recorded Salmo trutta Linnaeus, 1758, T. croaticus, Paraphoxinus ghetaldii Steindachner, 1882 (probably a wrong determination of Phoxinus lumaireul (Schinz, 1840)), Gobio obtusirostris Valenciennes, 1842 and Cobitis elongatoides Băcescu et Mayer, 1969 in several streams of the Zrmanja basin around the town of Gospić (Ričica, Krivak, Suvaja, Banica, Otuča and Opsenica). No native (indigenous) populations of the genus Squalius Bonaparte, 1837 exist in the Lika region, except for the introduced S. cephalus (Linnaeus, 1758) which originates from the Black Sea drainage basin (Bogutskaya \& Zupančič 1999, Zupančič 2010) and S. zrmanjae Karaman, 1928 from the Zrmanja River. Kottelat and Freyhoff (2007) cite Padogobius bonelli (Bonaparte, 1846) and Pomatoschistus canestrinii (Ninni, 1883) for the 
Ričica River. These species were most likely introduced by reverse hydropower plant from the Zrmanja River, where they have been recorded before (Mrakovčić et al. 1995). Formerly it was presumed only one species of brown trout in the Lika region, but recent studies show two distinct lineages: Danube lineage (S. labrax Pallas, 1814) and Atlantic lineage (S. trutta Linnaeus, 1758) (JADAN et al. 2007). These two species had also interbred after uncontrolled restocking and it is not possible to distinct them with certainty.

Karstic rivers of Lika region are oligotrophic by origin and characterized by large water oscillations and low yearly mean water temperatures $\left(\sim 9{ }^{\circ} \mathrm{C}\right.$; for more details see BonACCI \& ANDRIć 2008). Based on available climatic data (Table 1), Lika plateau altitude and terrain slope, we expect these waters to be naturally inhabited by coldwater fish species. Long-lasting human impact on these rivers is increasingly evident in shifts towards water eutrophication and increase of average water temperatures. Main causes for these changes are suspected to be global climate change and large human alternations (see $\check{Z}_{\text {GANEC }} 2012$ for data on rivers from Gorski kotar). However, the impact of accumulated alien biomass on these systems has never been assessed. The aim of this study was to explore negative impacts of non-native species domination over native fish populations in the Lika region. This example is a case study providing valuable insights on how these negative impacts affect Dinaric Arc Karst systems. In addition, a critical review of recent distribution of four endemic fish species is given, with the emphasis on the importance and need for strict protection of river headwaters as their last refuge.

\section{MATERIAL AND METHODS}

\section{Study area characteristics}

Lika is a vast, elliptically shaped basin bordered with arched rows of towering mountain ridges of Mala Kapela and Plješivica mountains whose bottom lies at an average altitude of 500-700 meters a.s.l. Climatic data of the study area is given in Table 1. Lika region can be divided into three smaller parts: 1) Gacka River with Brinje area, 2) Lika-Gračac basin with the Krbava River and Lika part of the Una River basin, and finally 3) OgulinPlaški basin (PAvić 1975). All rivers in the Lika region are characterized as karst sinking rivers and together they produce one of the largest and most interesting hydrogeological systems in Europe (Fig. 1). In hydrological terms this area can be divided into three large sub-areas where drainage basin of Gacka and Lika Rivers $\left(3000 \mathrm{~km}^{2}\right)$ and drainage basin of Zrmanja $\left(700 \mathrm{~km}^{2}\right)$ are parts of a larger Adriatic drainage basin, while drainage basin of Una river $\left(1200 \mathrm{~km}^{2}\right)$ is a part of the Black Sea drainage basin (MARкоvić et al. 2000).

Lika River rises at the foot of the Velebit Mountain in the southern part of Ličko polje at the altitude of about $600 \mathrm{~m}$ a.s.l. With its $78 \mathrm{~km}$ of length it is the largest sink river in Lika region and the second largest in Europe. Main tributaries of Lika are Novčica and Otešica from the left and Glamočnica and Jadova from the right. Besides these, Lika accepts a lot 
Table 1. Climatic data for larger towns in Lika region indicating cold alpine climate (source: Croatian Meteorological and Hydrological Service 2014).

\begin{tabular}{lcccccc}
\hline Month & \multicolumn{2}{c}{ Gospić } & \multicolumn{2}{c}{ Korenica } & \multicolumn{2}{c}{ Otočac } \\
& $\begin{array}{l}\text { average air } \\
\text { temp. }\left({ }^{\circ} \mathrm{C}\right)\end{array}$ & $\begin{array}{c}\text { precipita- } \\
\text { tion }(\mathrm{mm})\end{array}$ & $\begin{array}{c}\text { average air } \\
\text { temp. }\left({ }^{\circ} \mathrm{C}\right)\end{array}$ & $\begin{array}{c}\text { precipita- } \\
\text { tion }(\mathrm{mm})\end{array}$ & $\begin{array}{c}\text { average air } \\
\text { temp. }\left({ }^{\circ} \mathrm{C}\right)\end{array}$ & $\begin{array}{c}\text { precipita- } \\
\text { tion }(\mathrm{mm})\end{array}$ \\
\hline January & 0.3 & 96.7 & -0.5 & 41.3 & -0.2 & 97.6 \\
February & -1.6 & 84.4 & -2.9 & 97.8 & -2.8 & 77.6 \\
March & 5.1 & 75.4 & 3.9 & 86.5 & 5.3 & 63.3 \\
April & 10.3 & 91.0 & 8.9 & 93.0 & 10.0 & 48.2 \\
May & 13.5 & 103.8 & 11.9 & 141.3 & 13.3 & 93.9 \\
June & 18.7 & 81.4 & 16.7 & 77.6 & 18.9 & 45.3 \\
July & 20.7 & 43.4 & 18.6 & 78.3 & 20.4 & 64.3 \\
August & 20.9 & 22.9 & 18.6 & 56.0 & 20.1 & 19.5 \\
September & 15.7 & 121.3 & 14.2 & 134.5 & 16.1 & 117.3 \\
October & 10.2 & 165.4 & 9.2 & 111.3 & 9.4 & 103.9 \\
November & 5.6 & 176.0 & 4.4 & 165.7 & 5.2 & 159.5 \\
December & 1.6 & 126.4 & 0.6 & 90.3 & 1.0 & 77.2 \\
\hline
\end{tabular}

of smaller tributaries like Bogdanica, Brušanica, Lopuža, Rizvanuša, Rakovac, Bužimica, Počiteljica, Crno vrelo and Balatin. It has a typical canyon/gorge riverbed formed by water cutting through the underlying limestone and dolomite rocks. Krušćica reservoir was formed in 1971 by a dam built in the lower part of the river canyon, near the village Mlakva in Kosinj. Afterwards, the river continues its flow to Lipovo polje where it is redirected from its sink hole to Gacka River through the Lika-Gacka tunnel.

Ričica, Otuča and Opsenica Rivers are parts of Zrmanja River drainage basin with which they are connected through underground flows. They are rising through various springs, with Krupa and Krnjeza Rivers being the largest (BonAcCI 1990). Štikada reservoir $\left(13650000 \mathrm{~m}^{3}\right.$ ) was built on Ričica River in the period from 1978 to 1985 as a part of Velebit reverse hydro-power plant complex. The lake was subsequently connected to Opsenica reservoir $\left(2700000 \mathrm{~m}^{3}\right)$ and Otuča River to obtain better water supply.

Krbava and Matica (Korenica), streams of Krbavsko and Koreničko poljes, are parts of the smallest Una River drainage basin. Water from both poljes sinks and flows underground to the Una River spring in the vicinity of Donji Srb village.

\section{Methods used}

During the period from 2006 to 2013 a total of 51 locations on four distinct drainages in the Lika region were sampled (Lika and Jadova; Gacka; Ričica, Otuča and Opsenica; Matica and Krbavsko polje). Sites were chosen according to accessibility and absence of mine fields (Table 2, Fig. 1). Standard fishing equipment was used, according to size and depth of a specific water body. Three one-layer nets were used: 1) $50 \mathrm{~m} \times 2.2 \mathrm{~m}$, eye diameter $6 \mathrm{~cm}$; 2) $19 \mathrm{~m} \times 3 \mathrm{~m}$, e. d. $4 \mathrm{~cm}$; 3) $23.5 \mathrm{~m} \times 1.4 \mathrm{~m}$, e. d. $2 \mathrm{~cm}$ ). Nets were set up in the water overnight and pulled out in the morning. SAMUS 725MP backpack device for 


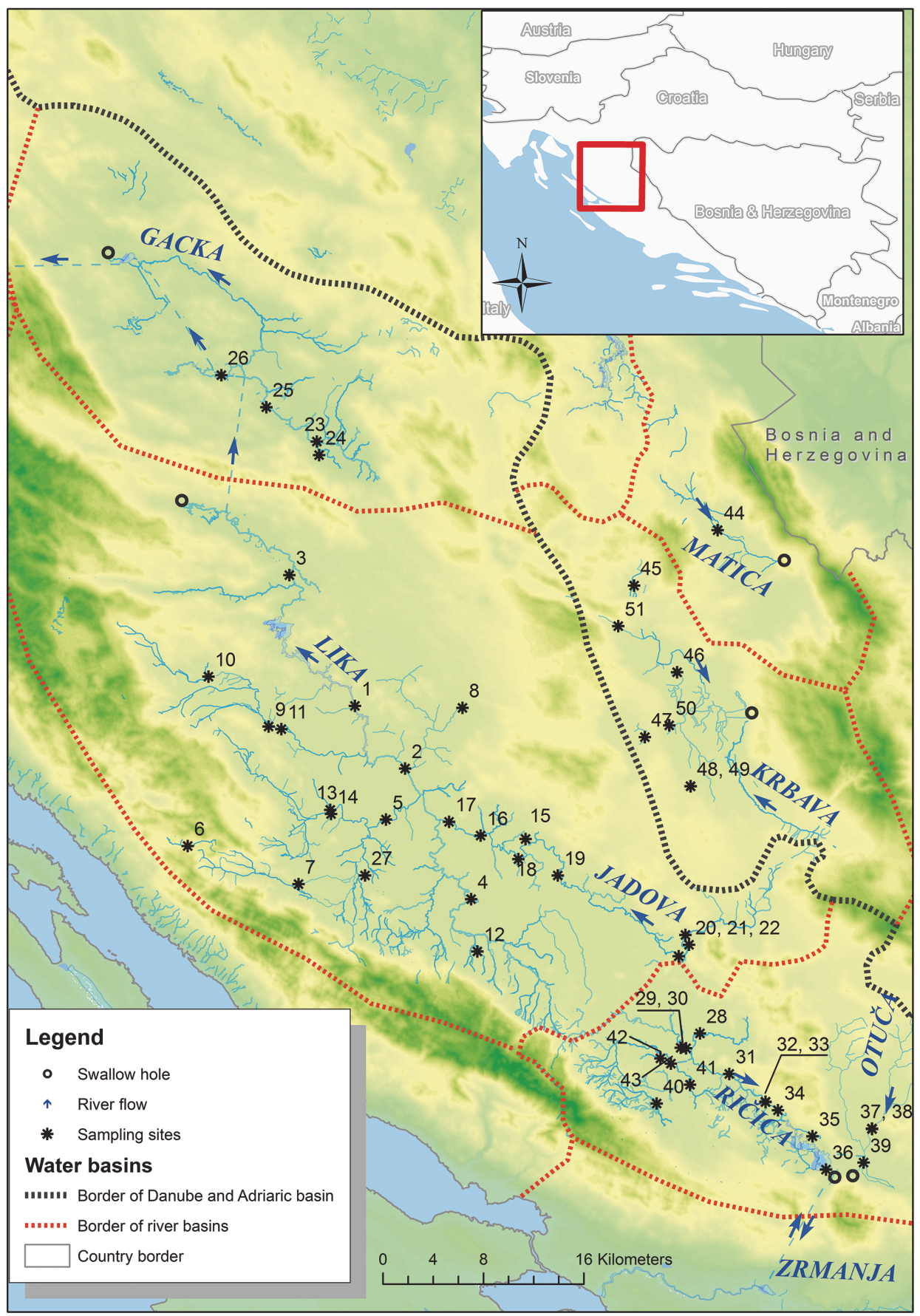

Fig. 1. River systems of high Lika plateau with all 51 sampling sites. 
Table 2. List of localities visited (plotted in Fig. 1; X and $Y$ are presented in Gauss-Kruger 5th zone coordinate system) in the high Lika plateau, habitat types, sampling methods and effort (fishing hours). Abbreviations: electrofishing = EF, fishing nets = FN, diving = D.

\begin{tabular}{|c|c|c|c|c|c|c|}
\hline Code & Locality & $X$ & Y & Habitat & Method & Effort \\
\hline 1 & Lika, Malo selo & 5527632 & 4942417 & Main river & $\mathrm{EF} / \mathrm{FN}$ & 8 \\
\hline 2 & Lika, Gospić bridge & 5531631 & 4937431 & Main river & $\mathrm{EF} / \mathrm{FN}$ & 8 \\
\hline 3 & Lika, Kosinj & 5522415 & 4952842 & Lake & $\mathrm{EF} / \mathrm{FN}$ & 8 \\
\hline 4 & Lika, Lički Ribnik & 5536899 & 4927023 & Main river & $\mathrm{EF} / \mathrm{FN}$ & 8 \\
\hline 5 & Novčica in Gospić & 5530112 & 4933366 & Main river & $\mathrm{EF} / \mathrm{FN}$ & 8 \\
\hline 6 & Ljubica, Oštarijsko field & 5514320 & 4931264 & Stream & $\mathrm{EF}$ & 1 \\
\hline 7 & Brušanica, Suvaja & 5523144 & 4928221 & Stream & $\mathrm{EF}$ & 1 \\
\hline 8 & $\begin{array}{l}\text { Lički Osik, Široka Kula, } \\
\text { Balatin stream }\end{array}$ & 5536210 & 4942267 & $\begin{array}{l}\text { Stream / } \\
\text { spring }\end{array}$ & EF & 1 \\
\hline 9 & Otešica, Jelići & 5520763 & 4940779 & Main river & $\mathrm{EF}$ & 2 \\
\hline 10 & Otešica, Pazarišnica & 5515969 & 4944748 & Main river & $\mathrm{EF}$ & 1 \\
\hline 11 & Otešica, Rastoke & 5521775 & 4940573 & Main river & $\mathrm{EF}$ & 2 \\
\hline 12 & Počiteljica, Medak & 5537394 & 4922853 & Main river & $\mathrm{EF}$ & 1 \\
\hline 13 & Bogdanica, Kaniža Gospićka & 5525668 & 4934143 & Main river & $\mathrm{EF}$ & 4 \\
\hline 14 & Bogdanica, Zablato & 5525736 & 4933808 & $\begin{array}{l}\text { Main } \\
\text { river }\end{array}$ & $\mathrm{EF}$ & 4 \\
\hline 15 & $\begin{array}{l}\text { Jadova, Vrebac, Gradina } \\
\text { village }\end{array}$ & 5541226 & 4931818 & Main river & $\mathrm{EF}$ & 4 \\
\hline 16 & Jadova, Barlete & 5537644 & 4932090 & Main river & $\mathrm{EF}$ & 4 \\
\hline 17 & Jadova, under the highway & 5535134 & 4933189 & Main river & $\mathrm{EF}$ & 4 \\
\hline 18 & Jadova, Vrebac location 3 & 5540653 & 4930218 & Main river & $\mathrm{EF}$ & 4 \\
\hline 19 & Jadova, Vrebac location 4 & 5543799 & 4928918 & Main river & $\mathrm{EF}$ & 4 \\
\hline 20 & Jadova/Suvaja, field spring & 5554256 & 4923393 & Spring & $\mathrm{EF}$ & 2 \\
\hline 21 & $\begin{array}{l}\text { Jadova/Suvaja, Suvaja } \\
\text { spring, Lazići }\end{array}$ & 5553974 & 4924170 & Spring & $\mathrm{EF}$ & 1 \\
\hline 22 & $\begin{array}{l}\text { Jadova/Suvaja, pool, Gornja } \\
\text { ploča }\end{array}$ & 5553431 & 4922486 & Main river & $\mathrm{EF}$ & 4 \\
\hline 23 & Gacka, Čovići bridge & 5524602 & 4963479 & Main river & $\mathrm{EF}$ & 4 \\
\hline 24 & $\begin{array}{l}\text { Gacka, Perušić, } \\
\text { Kostelka,Plasina bridge }\end{array}$ & 5524785 & 4962400 & Main river & $\mathrm{EF}$ & 6 \\
\hline 25 & Gacka, Perušić, Obilje & 5520572 & 4966213 & Main river & $\mathrm{EF}$ & 6 \\
\hline 26 & $\begin{array}{l}\text { Gacka, Perušić, Otočac, un- } \\
\text { der the highway }\end{array}$ & 5516995 & 4968768 & Main river & $\mathrm{EF}$ & 6 \\
\hline 27 & Gacka, Perušić, Sv. Franjo & 5528440 & 4928918 & Main river & EF & 4 \\
\hline
\end{tabular}


Table 2 (continued)

\begin{tabular}{|c|c|c|c|c|c|c|}
\hline Code & Locality & $x$ & $\mathrm{Y}$ & Habitat & Method & Effort \\
\hline 28 & $\begin{array}{l}\text { Ričica, Lovinac, Kuzminac } \\
\text { spring }\end{array}$ & 5555125 & 4916330 & Spring & $\mathrm{EF}$ & 6 \\
\hline 29 & $\begin{array}{l}\text { Ričica, upper part, Lovinac } \\
\text { bridge }\end{array}$ & 5554017 & 4915147 & Main river & $\mathrm{EF}$ & 2 \\
\hline 30 & $\begin{array}{l}\text { Ričica, upper part, Veliki } \\
\text { Bregovac }\end{array}$ & 5553590 & 4915193 & Main river & $\mathrm{EF}$ & 2 \\
\hline 31 & Ričica, middle part & 5557456 & 4913106 & Main river & EF & 8 \\
\hline 32 & Ričica, Tomičići & 5560346 & 4910864 & Main river & EF & 4 \\
\hline 33 & Ričica, Ličko Cerje & 5560349 & 4910896 & Main river & EF & 4 \\
\hline 34 & Ričica, lower part & 5561335 & 4910214 & Main river & EF & 4 \\
\hline 35 & Ričica, lower part, Štikada & 5564091 & 4908141 & $\begin{array}{l}\text { Accumu- } \\
\text { lation }\end{array}$ & $\mathrm{EF}$ & 4 \\
\hline 36 & Ričica, Štikada, Gračac & 5565166 & 4905491 & $\begin{array}{l}\text { Accumu- } \\
\text { lation }\end{array}$ & $\mathrm{EF}$ & 6 \\
\hline 37 & Otuča, Gračac & 5568832 & 4908755 & Main river & $\mathrm{EF}$ & 4 \\
\hline 38 & Otuča, Ričica tributary & 5568841 & 4908711 & Main river & EF & 4 \\
\hline 39 & Otuča, Žižinka, Gračac & 5568167 & 4906045 & Main river & EF & 2 \\
\hline 40 & Opsenica, towards Mali Alan & 5551682 & 4910743 & Main river & EF & 1 \\
\hline 41 & Opsenica, upper part & 5554328 & 4912245 & Main river & EF & 2 \\
\hline 42 & Opsenica, lower part & 5551970 & 4914346 & Main river & EF & 2 \\
\hline 43 & Opsenica, sv. Rok Lake & 5552811 & 4913923 & $\begin{array}{l}\text { Accumu- } \\
\text { lation }\end{array}$ & EF & 4 \\
\hline 44 & Matica (Titova Korenica) & 5556530 & 4956423 & Main river & EF & 4 \\
\hline 45 & Krbavica & 5549881 & 4952008 & Main river & EF & 2 \\
\hline 46 & $\begin{array}{l}\text { Krbavsko polje, Laudanov } \\
\text { gaj }\end{array}$ & 5553307 & 4945105 & Pond & EF & 6 \\
\hline 47 & $\begin{array}{l}\text { Krbavsko polje, Podlapačko } \\
\text { polje }\end{array}$ & 5550739 & 4939938 & $\begin{array}{l}\text { Spring / } \\
\text { Cave }\end{array}$ & EF & 1 \\
\hline 48 & $\begin{array}{l}\text { Krbavsko polje, Suvaja Me- } \\
\text { kinjarska }\end{array}$ & 5554375 & 4936020 & Stream & $\mathrm{EF}$ & 4 \\
\hline 49 & Krbavsko polje, Suvaja cave & 5554383 & 4936013 & $\begin{array}{l}\text { Spring / } \\
\text { Cave }\end{array}$ & $\mathrm{EF} / \mathrm{D}$ & 2 \\
\hline 50 & Krbavsko polje, Vukova cave & 5552674 & 4940873 & $\begin{array}{l}\text { Spring / } \\
\text { Cave }\end{array}$ & $\mathrm{EF}$ & 6 \\
\hline 51 & $\begin{array}{l}\text { Krbavsko polje, Zelena cave } \\
\text { (Bunić) }\end{array}$ & 5548620 & 4948772 & $\begin{array}{l}\text { Spring / } \\
\text { Cave }\end{array}$ & $\mathrm{EF} / \mathrm{D}$ & 2 \\
\hline
\end{tabular}


electrofishing was also used for fish sampling. It produces pulse direct electric current with $650 \mathrm{~W}$ maximum power (1000 V, 10-20 A). Methods used and fishing effort for each locality are listed in Table 2 for reference. Larger fish specimens were measured and released at the spot while the rest of the catch was preserved in $4 \%$ formaldehyde solution and processed in the laboratory. Fish species were determined using relevant fish identification keys (Vuković \& Ivanović 1971, Povž \& Sket 1990, Maitland 2000, Kottelat \& Freyhoff 2007). Total (TL) and standard length (SL) were measured by ichthyometer with the nearest millimeter precision. Weight of each fish specimen was measured by a digital scale with the 0.1 gram precision.

Microsoft Excel (Microsoft Office 2010 package) was used for numeric data analysis and tables. ArcGiS 9.3 (Environmental Systems Research Institute 2009) was used for geographical analysis and production of distribution maps.

\section{RESULTS}

Altogether 26 species and 8 families of fish with 2084 specimens were recorded (Table 3 ) during the research. Five more species were listed from analysing fishermen catch: Anguilla anguilla, Cyprinus carpio Linnaeus, 1758, Ctenopharyngodon idella (Valenciennes, 1844), Hypophthalmichthys nobilis (Richardson, 1845) and Silurus glanis Linnaeus, 1758. When combined, a total of 31 species of freshwater fish was registered in the research area (Table 3). The species were assigned to 10 different families. According to species number Cyprinidae family had the biggest share in overall catch with 18 species (58\%). Families Salmonidae, Cobitidae, Gobiidae and Percidae were represented with two species (6.5\%). Anguillidae, Blennidae, Centrarchidae, Esocidae i Siluridae were represented with one species $(3 \%$ of overall family number; Table 3).

In terms of abundance Salmo sp. Linnaeus, 1758 was the most dominant species in overall catch with 336 specimens caught (16\% of overall catch). Subdominant species were as follows: Rutilus rutilus (Linnaeus, 1758) (12\%), Lepomis gibbosus (Linnaeus, 1758) (11\%) and S. cephalus (11\%). Numerically least represented species (with less than $1 \%$ of specimens in overall catch) were Salaria fluviatilis (Asso, 1801), Misgurnus fossilis (Linnaeus, 1758), Oncorhynchus mykiss (Walbaum, 1792), Scardinius erythrophthalmus (Linnaeus, 1758), Phoxinus phoxinus (Linnaeus, 1758), T. fontinalis, C. jadovaensis Mustafić and Mrakovčić, 2008 and Carassius carassius (Linnaeus, 1758). Among the 31 determined species only eight were autochthonous: Salmo sp., Delminichthys krbavensis (Zupančič et Bogutskaya, 2002), D. jadovensis (Zupančič et Bogutskaya, 2002), P. phoxinus, T. croaticus, C. jadovaensis, T. fontinalis and A. anguilla, making up $26 \%$ of recorded species. Among the 23 allochthonous species (74\%) 21 species are invasive, comprising almost $2 / 3$ of overall catch. Complete data on species number and individuals recorded in each of 51 sampled sites are listed in Appendix 1. 


\section{Lika and Jadova}

Investigation on Lika and Jadova Rivers was conducted on 22 sites. Altogether 984 specimens classified into 14 species and 6 families were recorded. The most abundant family was Cyprinidae with 8 species, followed by family Percidae with two species. All other families (Salmonidae, Centrarchidae, Esocidae and Cobitidae) were represented with just one species per family. The most common species in Lika River was $R$. rutilus (30\%), followed by S. cephalus (18\%), Alburnus alburnus (Linnaeus, 1758) (16\%), Perca fluviatilis Linnaeus, $1758(15 \%)$ and L. gibbosus (8\%). Other species were represented in smaller percentage. The most abundant species in Jadova were S. cephalus $(31 \%), R$. rutilus $(21 \%)$, D. jadovensis $(17 \%)$ and L. gibbosus $(12 \%)$. Species with lower abundance were T. croaticus (7\%) and Tinca tinca (Linnaeus, 1758) $(7 \%)$. Other species were represented with less than $3 \%$. Overall, 10 allochthonous species (A. alburnus, C. carassius, R. rutilus, T. tinca, L. gibbosus, S. cephalus, S. erythrophtalmus, P. fluviatilis and E. lucius) making up $87 \%$ of the total catch were recorded, mostly in Lika and lower parts of Jadova. The native species Salmo sp. (S. trutta / S. labrax / S. farioides; still unresolved taxonomic status), was found only in the upper parts of Lika River and its tributaries because of strong human impact in lower parts. Endemic species (C. jadovaensis, D. jadovensis and T. croaticus) were only found in the upper parts of Jadova and a stream called Suvaja (upstream from village Gornja Ploča). A. anguilla was not recorded in any of the sampling sites.

\section{Gacka}

Gacka River was investigated on 5 sites. A total of 251 fish specimens divided into 9 species and 6 families were recorded. Family Cyprinidae was the most abundant with three species, while Salmonidae contributed with two species. All other families (Percidae, Centrarchidae, Esocidae and Cobitidae) were represented with just one species per family. The most common species was Salmo sp. (probably S. labrax) (78\%) followed by E. lucius (9\%). Other species were represented with less than $5 \%$. There were eight alien species recorded (R. rutilus, T. tinca, L. gibbosus, S. cephalus, P. fluviatilis, E. lucius, M. fossilis and O. mykiss) making up $23 \%$ of total catch.

\section{Ričica, Otuča and Opsenica}

Ričica, Otuča and Opsenica streams were investigated on 16 sites. Overall, 646 fish specimens grouped into 11 species and 5 families were determined. The most abundant family Cyprinidae contributed with 6 species, followed 


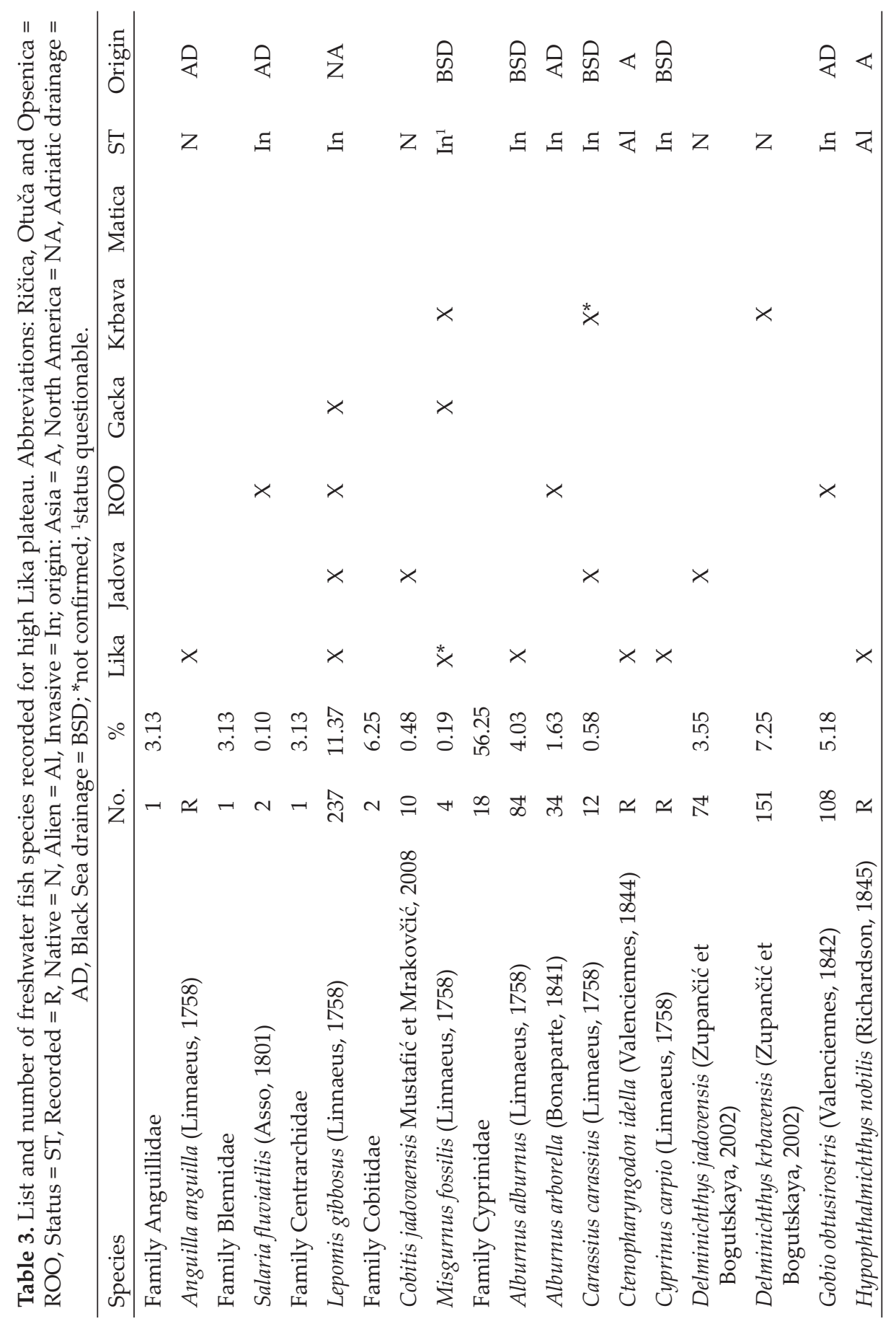




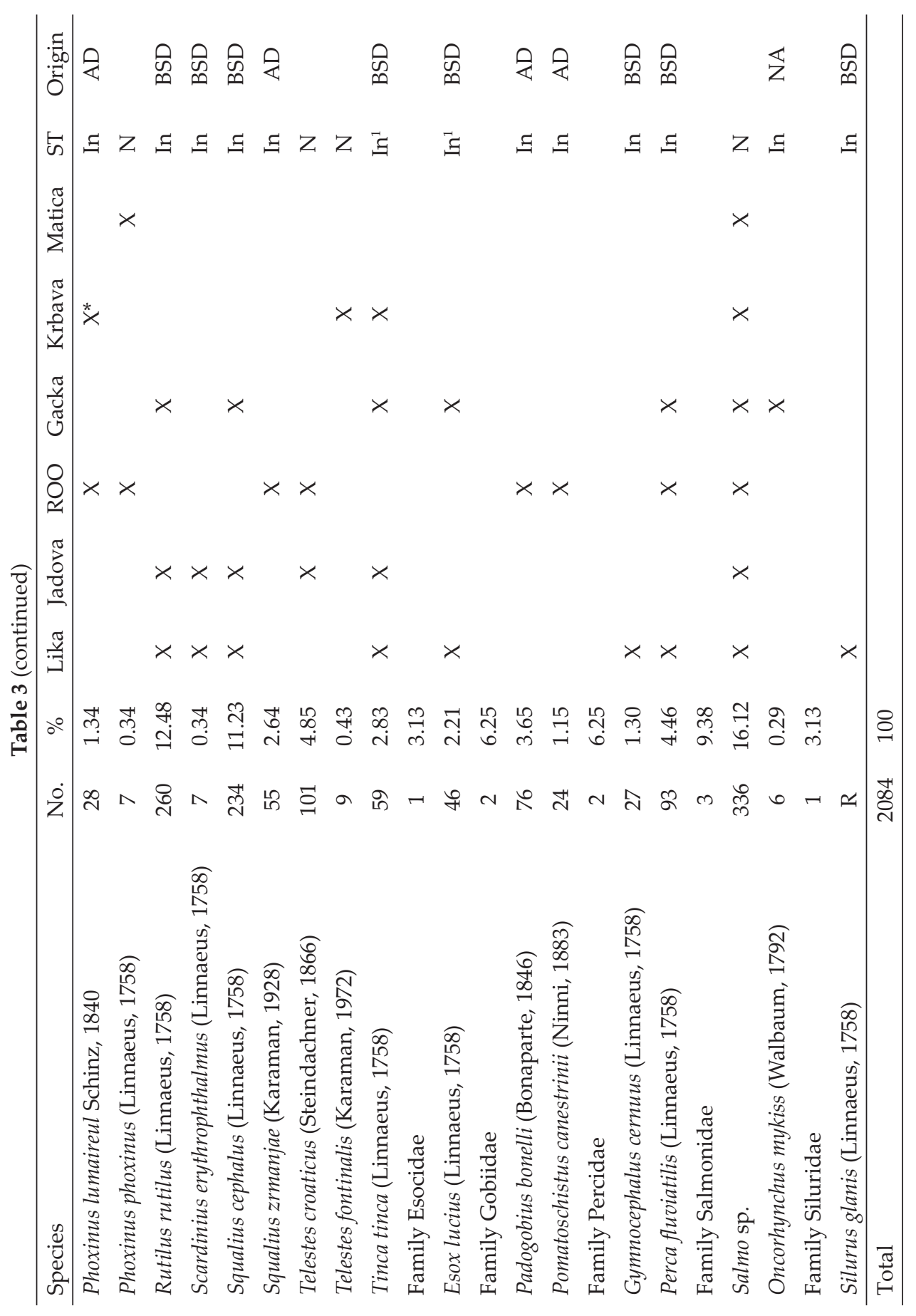


by Gobiidae with 2 species. The other three families recorded (Salmonidae, Centrarchidae and Blennidae) were each represented with just one species. The most common species were L. gibbosus (22\%), G. obtusirostris (17\%), Salmo sp. $(17 \%)$, P. bonelli (12\%), T. croaticus (11\%), and S. zrmanjae (9\%). All of the remaining species were represented with less than $5 \%$. However, the presented data arose from intentional effort to map remaining distribution of T. croaticus in Ričica. Therefore, potentially favourable habitats for this species were more frequently sampled, and very large number of P. lumaireul and S. zrmanjae were not collected even when seen stunned in the water, which could lead to misleading or even biased interpretation of data. Eight alien species ( $L$. gibbosus, S. zrmanjae, Alburnus arborella (Bonaparte, 1841), P. lumaireul, G. obtusirostris, P. bonelli, P. canestrinii and S. fluviatilis) comprised $72 \%$ of total catch. Most of them reached Ričica through reverse hydro-power plant "Velebit" from the Zrmanja River. The only native species recorded was T. croaticus, while the origin of Salmo sp. is unknown. Alien species were mostly located in reservoirs Štikada on Ričica and Sv. Rok on Opsenica.

\section{Matica and Krbausko polje streams}

The research of Matica River and streams in Krbavsko polje was conducted on 8 sites. A total of 203 fish specimens were caught, classified into 7 species and 2 families: Cyprinidae with 6 species, and Salmonidae with one taxa, Salmo sp. (probably S. labrax). The most frequent species in Krbavsko polje was D. krbavensis (74\%), followed by Salmo sp. (10\%), whilst other species were represented with less than $5 \%$. Of all species recorded, 4 were allochthonous (C. carassius, M. fossilis, T. tinca and P. phoxinus which is allochthonous only for Krbavsko polje streams) with $8 \%$ of total catch. Altogether, 4 native species comprising $92 \%$ of total fish catch were noted: D. krbavensis and T. fontinalis in Krbavsko polje, and P. phoxinus and Salmo sp. (S. labrax) in Matica. $D$. krbavensis and T. fontinalis occurred in the polje only during high water levels when it becomes a large floodplain (usually from December to April). As the water retreats into underground fish also retreat back into springs, sinks and estavelas. Also, a number of small ponds, springs and cave systems (i.e. Suvaja Mekinjarska, Pećine, Vukova pećina, Hrnjakova pećina and sinkholes in Podlapačko polje) exist throughout the year in polje where the fish can be found during dry season. Present distribution of endemic Telestes and Delminichthys species is presented in Figure 2 and 3. They can be considered extinct form all other localities mentioned in the literature. 


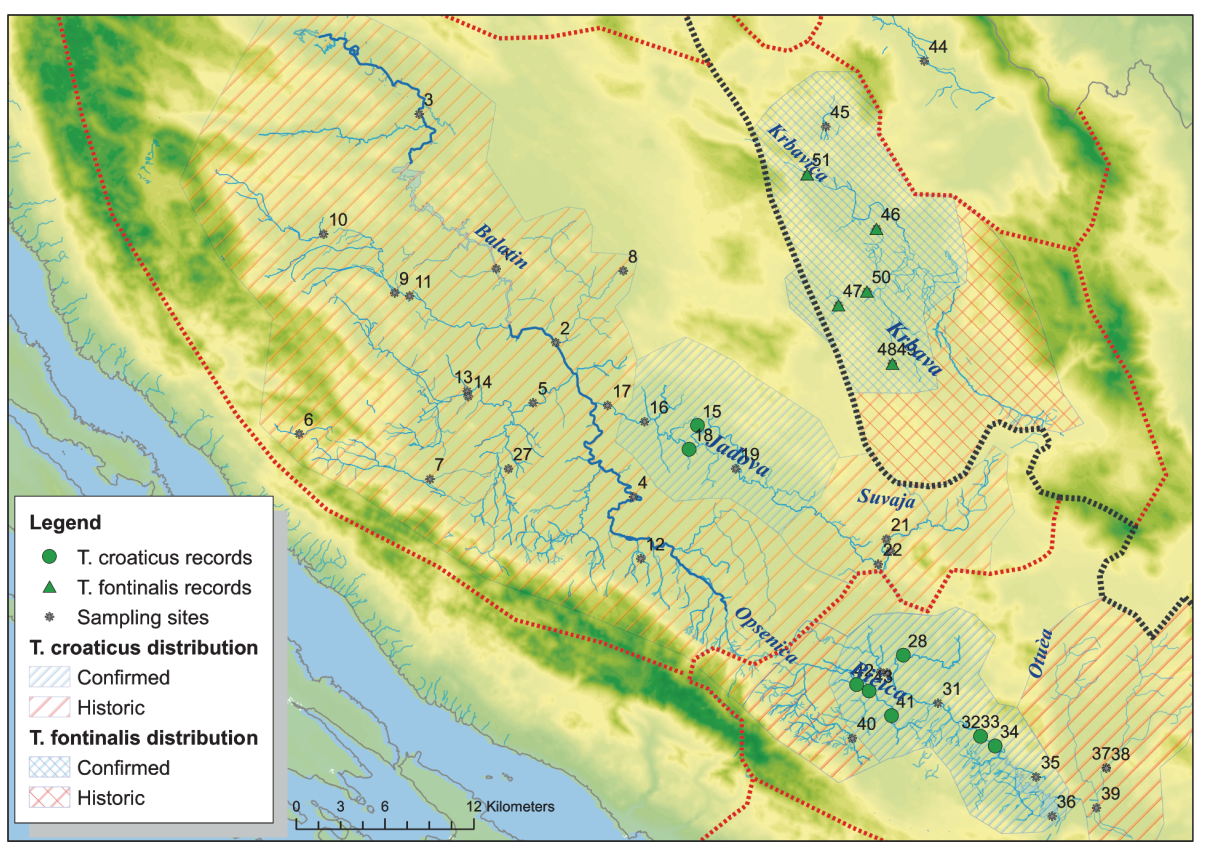

Fig. 2. Distribution of endangered Telestes fontinalis and T. croaticus.

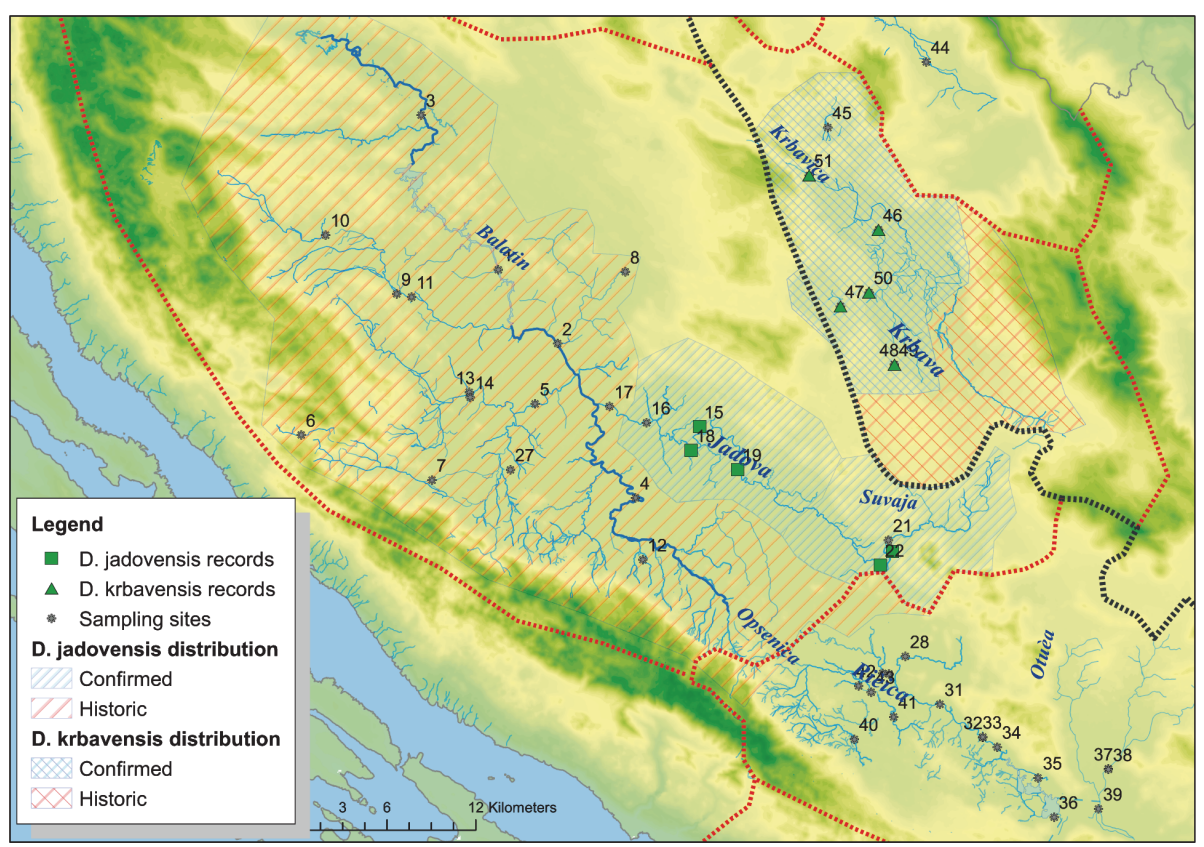

Fig. 3. Distribution of endangered Delminichthys krbavensis and D. jadovensis. 
Table 4. Year of introduction for alien fish species in the Lika River. ŠRU "Lika" Gospić (2014) is a citation of a local fishing organization data on fish introduction and stocking from 1900-2014.

\begin{tabular}{lcc}
\hline Species & Year of introduction & Reference \\
\hline Alburnus alburnus & Unknown & ŠRU “LiKA” GosPić (2014) \\
Esox lucius & 1967 & K. P. (1968) \\
Gymnocephalus cernuus & 1937 & ŠRU “LiKA” GosPić (2014) \\
Lepomis gibbosus & $1935-1936$ & Pl. (1946); K. P. (1968) \\
Squalius cephalus & $1935-1936$ & K. P. (1968) \\
Perca fluviatilis & 1937 & ŠRU “LiKA” GosPić (2014) \\
Rutilus rutilus & $1935-1936$ & K. P. (1968) \\
Tinca tinca & 1972 & ŠRU “LiKA” GosPIć (2014) \\
Scardinius erythrophthalmus & 1937 & ŠRU “LiKA” GosPić (2014) \\
Cyprinus carpio & $1933 ; 1935-1936$ & Pl. (1946); K. P. (1968) \\
Carassius carassius & $1935-1936$ & Pl. (1946); K. P. (1968) \\
\hline
\end{tabular}

\section{Introduced species}

Since the middle of the 20th century a significant number of alien fish species (Table 4) was introduced to Lika region, of which some became potentially invasive. Moreover, alien species stocking was done by anglers to increase the number of fish species in streams.

Alien species can be principally divided into two groups: generally allochthonous and locally allochthonous. In Croatia, generally allochthonous species are not naturally occurring in Croatian waters, whilst locally allochthonous species are native for Croatia, but are introduced into habitats in which they do not occur naturally. Besides the introduced European species, generally allochthonous fish species in Croatia originate from Asia and North America. Generally allochthonous species in Lika are represented with four species: C. idella, H. nobilis, O. mykiss and L. gibbosus. Other alien species are locally allochthonous, either from the Black Sea drainage or from other parts of the Adriatic drainage. A. alburnus, C. carassius, C. carpio, E. lucius, G. obtusirostris, G. cernuus, M. fossilis, P. fluviatilis, R. rutilus, S. erythropthalmus, S. glanis, S. cephalus and T. tinca originate from the Black Sea drainage, while $A$. arborella, P. bonelli, P. canestrinii, S. fluviatilis, P. lumaireul and S. zrmanjae originate from the Adriatic drainage (Zrmanja River). Invasive species are alien species that are harming and destroying native populations while reproducing and spreading into invaded area. They do so through predation, resource exploitation, interbreeding with native species or occupation of ecological 
niche (European Environment Agency 2012). All of the species listed above can be considered invasive except for C. idella and H. nobilis.

\section{DISCUSSION}

\section{Native species}

Species native to Lika region were as follows: T. croaticus, T. fontinalis, $D$. krbavensis, D. jadovensis, and C. jadovaensis (Mustafić et al. 2008). One taxa of brown trout (classified as Salmo sp.), A. anguilla and P. phoxinus are presumably native species, but further research is needed for confirmation of their status. The origin of brown trout in the Lika region is fairly unsolved, since no clear conclusions about its biogeographical or phylogenetic status exist. A plausible claim for the existence of trouts in the region could be the undocumented anthropogenic introduction of trouts from Danube, Atlantic and/or Adriatic lineages in the past (as indicated for Gacka in JADAN et al. 2007). It is possible that trouts are not native to high Lika plateau, due to their geographic isolation, and that all three Salmo sp. taxa have been introduced. One confirmation to the "introduction of trouts" theory is no records of Cottus gobio Linnaeus, 1758 in any of the river systems of Lika plateau, although they are found together with trouts in all surrounding regions (Dobra and Mrežnica in Gorski kotar; Una River to the North; and Zrmanja and Krka Rivers to the east and south; Jelić 2011). Cold climate (indicated by meteorological data in Table 1), slope and high altitude should promote life of cold adapted fish species and inhibit introduction of warm adapted species. Salmonids would find a favourable habitat for their dispersal no matter if appearing here naturally through drainage shifts (TAKÁcs et al. 2014) or through historical human introduction.

P. phoxinus is native in the Matica River, while populations found in $\mathrm{Kr}-$ bavsko polje (Krbavica) and Ričica River are probably introduced. Franić (1900b) stated that in Balatin stream two species of fish ("pijor" and "čikov") appear during long periods of floods. As this tributary of Lika River is very similar to Jadova River, we presume that these are D. jadovensis and C. jadovaensis (often called "pijor" and "čikov" among local people). We assume Paraphoxinus adspersus in Balatin mentioned by Trgovčević $(1905,1908,1932)$ is probably also referring to $D$. jadovensis because the author emphasizes it as a separate species and clearly separates it from $T$. croaticus. Balatin stream was sampled four times on several locations during the research but no specimens of Delminichthys, Telestes or Cobitis were found. Varieties of larger springs in the surrounding area were sampled (Jezerina and Studenac in Siroka kula, a spring in Prvan Selo, etc.) by means of electrofishing and diving (visual obser- 
vation) as potential habitats for Delminichthys and Telestes genus species, but the efforts also yielded no recent records. Phoxinus ghetaldii, a species listed for Ričica by НABEKović et al. (1992), could probably be a mistakenly identified $P$. lumaireul introduced to Ričica from the Zrmanja River. $P$. ghetaldii is native to southern Herzegovina and Dalmatia, while $P$. lumaireul is a species very common in the investigated area. Another possibility is that this population belongs to an unidentified Delminichthys sp., because Ričica is the only habitat in Lika region solely populated by Telestes sp. In both Krbavsko polje and Jadova River we found one species of Telestes and Delminichthys living in sympatry, and often in syntopy.

A. anguilla should be considered as native species as it was historically recorded in the Lika River (Kosinj stream in LANGHofer 1904, Trgovčević 1908 , not found during this study). Even though eels are native in the Adriatic drainage basin and Lika region is hydrologically partly connected to the Adriatic Sea via underground flows, it was never confirmed that eels can migrate through those waterways to complete their life cycle.

\section{Questionable species}

Several problems and uncertainties arise when designating reference status to species with none or very little documented records, for example whether species common to the Black Sea drainage area, like E. lucius, $M$. fossilis and T. tinca (Table 3), should really be indicated as non-native at these Adriatic drainage sub-areas. Changes of the topographic and hydrographic conditions could cause these sub-areas to be shifted to another drainage (TAKÁcs et al. 2014), leaving the possibility that Gacka, Lika and Jadova Rivers used to be in a direct contact with the Black Sea, and thus effectively explaining the appearance of the species. Furthermore, it should be taken into consideration that the samples collected with the latest research methods are fairly difficult to compare with those of the researches done many decades before.

FrANić (1900a) claimed that Gacka receives water from Lika River swallow hole because their water levels are precisely correlated, which is in accordance with the findings of several recent hydro-geological investigations (Bonacci \& ANdrić 2008, Lukač Reberski et al. 2013). He also stated that large amounts of fish "pijor" (local name for minnow) appear in one well in Kompolje (NW of Otočac) when there is high water input in the Lika River swallow hole, and that this "pijor" is only present in Lika and not in the Gacka River. BRUSINA (1892) also indicated presence of an unknown minnow in Konjsko polje (Kompolje) that appeared with high waters from the underground. No species of minnow was ever recorded in Gacka and these findings have to 
correspond either to $D$. jadovensis arriving from Lika River, or to a new undescribed species.

\section{Invasive species}

A very concerning fact is that 23 out of 31 species are introduced (alien species) into this region as a direct result of intense and irresponsible stocking. The share of alien species in overall catch went from 0 (before human introduction) to 29 in less than 100 years of human intervention, with signs of further increase. This is even more evident in the overall fish biomass share, because in most cases introduced species tend to have either higher reproduction (KeLler et al. 2011) and resource uptake rates (AlEXANDER et al. 2014), faster growth rate (Albins 2013) or much larger body size compared to those in native species (VILA-Gispert et al. 2005). The share of allochthonous species in total recorded species was $66 \%$, while the share of invasive specimens in total catch was $67 \%$. L. gibbosus and S. cephalus cumulatively make up $22 \%$ of the total catch in the Lika region, representing a large new biomass input into these mostly oligotrophic ecosystems, leading to rapid eutrophication of the habitat, and thus making it unsuitable for native species. Furthermore, the newly established environmental settings create new habitats to introduced species, consequently increasing their biomass and speeding up the eutrophication. As a result, eutrophication causes the continued increase of average water temperature thereby favouring alien fish species (WHITEHEAD et al. 2012). Long human presence in these areas has also directly contributed to these negative effects through input of large amounts of organic waste into the systems and riverine alternations that slow down or disrupt the water flow. In addition to already constructed reservoirs for power stations, local community built a large number of smaller damps for the construction of water mills. Data from 1946 show the presence of small accumulation lakes every 3-4 km along the Lika River flow, causing the river to resemble a series of small lakes during dry months (PL. 1946). According to the same source the water in these lakes would rise up to $25^{\circ} \mathrm{C}$ during summer and local people started noticing a gradual disappearance of trouts. Habitat changes and scarcity of food forced local people to introduce warm-water alien fish species from other regions (PL. 1946, K. P. 1968). Introduced species undoubtedly influence populations of native species because many cannot be found in areas where they once thrived (RYDÉN et al. 2003), like T. croaticus in the Ljubica stream or D. jadovensis in the Balatin stream. Local people still report that in their youth these species were so abundant that river would become black when they would come out to breed and that they would catch hundreds of kilograms of them with simple wooden baskets (native type of fishing). Native species only remain in 
areas mostly inaccessible to introduced species, like the upper parts of Jadova, Ričica, and underground cave systems throughout the region, especially in Krbavsko polje. Several parts of Jadova and Krbava flow dry up during dry period (June to September), thus isolating the (most) upper parts populated with native ichthyofauna from the lower parts mostly populated by introduced species. Long evolution processes in Dinaric karst have made endemic species resistant to sessional dry periods and adapted them for retreats into deep underground aquifers (GunN 2004, Bonacci et al. 2009).

The effect of endemic fish species retreating into higher parts of headwaters when pressured by introduced species or pollution is also visible in other similar cases we investigated in Croatia and Bosnia and Herzegovina. Similar effect was observed in Cikola River (Dalmatia, Croatia) where two endemic species, Telestes turskyi (Heckel, 1843) and Phoxinellus dalmaticus Zupančič et Bogutskaya, 2000, have retreated in the uppermost parts of the river. The same case was observed with Telestes polylepis Steindachner, 1866, species endemic to Dobra and Zagorska Mrežnica Rivers (Gorski Kotar, Croatia), but now only found in one of the cave springs of Zagorska Mrežnica. Telestes metohiensis (Steindachner, 1901) and Delminichthys ghetaldii (Steindachner, 1882) populations in Herzegovina (South-Eastern Bosnia and Herzegovina) also exibit the same faith. Often, limiting factors for the dispersal of introduced species are natural barriers or parts of river that dry out during summer. This presents a very specific phenomenon of Dinaric Karst rivers, where middle parts completely dry out (or the water sinks into underground but continues to flow) but the headwaters and springs (including the spring caves) retain water permanently. These small reservoirs are sole sources for the survival of endemic species populations, and thus their adaptation to water oscillations and retreatment into underground. Therefore, these headwaters are also main priority for conservation action planning.

\section{Adaptation to cave life}

After the presentation of such an intensive over-domination of alien species the main question arising is how endemic native species manage to survive and do they have a future in this drainage. The largest populations of endemic $D$. jadovensis and T. croaticus can be found in upper parts of Jadova and Suvaja. These rivers do not have a permanent water flow, but are actually dry from June to September, during which fish retreat into "grabe" (local denomination for deeper ponds that retain water even during dry season, usually continuing into underground cave systems). Upper parts of Jadova and Suvaja are rich in large springs where $D$. jadovensis and T. croaticus retreat. When water comes back into the main streams fish also reappear for breed- 
ing. Several $D$. jadovensis were observed during dry period in Suvaja River (tributary of Jadova; location number 20) in a small cave spring during cave diving. T. fontinalis and D. krbavensis in the Krbavsko polje exhibit the same behaviour, spending even longer time in caves (8-10 months per year). Populations in the cave Suvaja Mekinjarska were never found to come out from the spring into the stream, and it seems there are no other areas where they could come out. Although the water level rises during spring and the stream starts to flow towards Krbava River, neither of the two species was recorded during 3 electrofishing occasions. It seems they are permanently confined to the cave system and spring pond. In January we observed many pregnant females of $\sim 16-18 \mathrm{~cm}$ total body length. Males were smaller (up to $14 \mathrm{~cm}$ of $\mathrm{TL}$ ) and very slender bodied. Over the course of several years in the Vukovića cave we observed hundreds of $D$. krbavensis specimens up to $12 \mathrm{~cm}$ of total body length coming out of the cave into a small pond for breeding (JanuaryMarch). For the most part of the year there is no water in the spring pond and fish are hidden underground. Due to spending majority of their lifetime in caves only with short-term surface rise-ups, D. jadovensis and D. krbavensis could be called "advanced stygophiles". T. fontinalis was also observed during cave diving, but in lower numbers and with smaller individuals (none over $10 \mathrm{~cm}$ of TL). This species was more commonly observed in permanent ponds and lakes in the lower parts of Krbavsko polje. Large population was found in ponds in Laudanov gaj, where they preferred vegetation and mud rich habitats. T. croaticus from the Ričica River was not found to enter cave systems, but mainly occupying open waters. In Kuzminac spring (village Lovinac, Ričica River) we observed several $T$. croaticus individuals emerging from the underground. T. fontinalis and T. croaticus could be referred to as "simple stygophiles", living principally above-ground and occasionally retreating into the caves (during summer or winter). We applied the terms "advanced" and "simple" in this terminology because we did not find any other expert terms to distinguish different types of stygophiles.

\section{Conservation of endemic species}

Because of such vast richness of endemic species characterizing Lika region, it is necessary to establish a stricter control of stocking with introduced species and to control the spread of already introduced ones. Any kind of water management should be strictly forbidden. Krbavsko polje still acts as a temporary karst lake and local people have learned to live with its natural water fluctuations. All of the infrastructure is built on the higher ground around the edges of polje, de facto representing the "know-how" of indigenous people about coexisting with nature and its implementation into practice. But 
this practical knowledge and experience is being lost and people nowadays are trying to build houses and set up agriculture in areas that flood during 10 year or 100 year maxima. This in return raises the need for hydrological regulations (channels, damps, tunnels, etc.) under the cover of protection of human property and lives. In poljes with this kind of yearly flood regime, we propose setting up historical boundaries of high water level and establishing a strict protection from any form of urbanization. Smaller poljes, like Krbavica and Podlapačko, also have similar water regimes and face the same problem. River systems also face similar problems with hydrological regulations and plans for hydropower usage. All of these changes cause rapid decline of endemic species (Mrakovčić et al. 2006).

As the importance of headwaters, river sources and underground cave systems for survival of endemic fish species has already been stated earlier in discussion, we can distinguish three most important areas for strict habitat conservation: 1) whole Jadova and Suvaja Rivers, 2) South-west part of Krbavsko polje (including Podlapačko polje) covering the drainage of Krbavica River, and 3) upper parts of Ričica River (from Štikada upwards) including the whole Opsenica River. These sites need to be included in Natura 2000 ecological network as important sites for endemic fish species. We also emphasize a need for an invasive species management plan for all three areas to prevent or control their dispersal.

D. jadovensis, D. krbavensis, T. fontinalis and C. jadovaensis are all considered globally Critically Endangered (CR) species (INTERNATIONAL Union For Conservation of Nature 2001) because of limited distribution range and observed population declines. T. croaticus is considered globally Endangered (EN) species (International Union for Conservation of Nature 2001). Our data indicate that it disappeared from Rivers Lika, Novčica, Balatin, Otuča and possibly Gacka, with a visible decline of population in Ričica River over the last 8 years. In 2007 and 2008 T. croaticus was still a very common species and we found it in several localities in large numbers (one female individual from the mid part of Ričica had $21 \mathrm{~cm}$ of total body length). In 2012 and 2013, during a $1500 \mathrm{~m}$ transect in a prime habitat (with two electrofishing devices), we caught just 34 individuals and more than $10 \mathrm{~kg}$ of $P$. phoxinus, S. cephalus, L. gibbosus and G. obtusirostris (data not included here because the sampling was done to reduce the number of invasive fish and decrease impact on $T$. croaticus). It is our proposition that $T$. croaticus be upgraded to a Critically Endangered species on the condition of observed population decline by at least $80 \%$ over a 10 -year period, where the reduction and its causes have not ceased and are not reversible - A2ace (estimated in INTERNATIONAL UNION FOR Conservation of Nature 2001). The fragmented range of T. croaticus and the 
existence of two distinct isolated populations, which ought to be treated as separate conservation units, should also be taken into further consideration.

Acknowledgements - Authors would like to thank the members of Croatian Biological Research Society and Biology Students Association BIUS for their help during data gathering. We owe a special gratitude to Mišel Jelić, Aljoša Duplić, Tea Bašić, Jure Miočić-Stošić, Ivana Sučić and Petra Pjevac.

\section{REFERENCES}

Albins, M. A. (2013) Effects of invasive Pacific red lionfish Pterois volitans versus a native predator on Bahamian coral-reef fish communities. Biological Invasions 15(1): 29-43. http://dx.doi.org/10.1007/s10530-012-0266-1

Alexander, M. E., Dick, J. T. A., Weyl, O. L. F., Robinson, T. B. \& Richardson, D. M. (2014) Existing and emerging high impact invasive species are characterized by higher functional responses than natives. Biology Letters 10: 20130946. http://dx.doi.org/10.1098/ rsbl.2013.0946

Bogutskaya, N. G. \& Zupančič, P. (1999) A re-description of Leuciscus zrmanjae and new data on the taxonomy of Leuciscus illyricus, L. svallize and L. cephalus (Pisces: Cyprinidae) in the West Balkans. Annalen des Naturhistorischen Museums in Wien 101B: 509-529.

BonACCI, O. (1990): Water circulation in karst and determination of catchment areas: example of the River Zrmanja. Hydrological Sciences 44(3): 373-386.

Bonacci, O., Gottstein, S. \& Roje-Bonacci, T. (2009) Negative impacts of grouting on the underground karst environment. Ecohydrology 2(4): 492-502. http://dx.doi. org/10.1002/eco.90

BonACCI, O. \& ANDrić, I. (2008) Karst rivers hydrology: case of the Lika and Gacka (Croatia). Acta Carsologica 37(2-3): 185-196.

Brusina, S. (1892) Pabirci za hrvatsku ihtiologiju i za ribarstvo. Glasnik Hrvatskoga naravoslovnog društva 7: 221-288. [in Croatian]

Commission of the European Communities (2008) Communication from the Commission to the Council, the European Parliament, the European Economic and Social Committee and the Committee of the Regions. Towards An EU strategy on invasive species. http://ec.europa. eu/environment/nature/invasivealien/docs/1_EN_resume_impact_assesment_ part1_v3.pdf [accessed at July 27th 2015]

Copp, G. H., Bianco, P. G., Bogutskaya, N. G., Erốs, T., Falka, I., Ferreira, M. T., Fox, M. G., Freyhof, J., Gozlan, R. E., Grabowska, J., Kováč, V., Moreno-Amich, R., Naseka, A. M., Peñáz, M., Povž, M., Przybylski, M., Robillard, M., Russell, I. C., Stakénas, S., Šumer, S., Vila-Gispert, A. \& Wiesner, C. (2005) To be, or not to be, a non-native freshwater fish? Journal of Applied Ichthyology 21: 242-262. http://dx.doi.org/10.1111/ j.1439-0426.2005.00690.x

Dumbović, V., Posavec Vukelić, V., Duplić, A., Katušić, L., Jelić, D., Boršić, I. \& Partl, A. (2009) Studija inventarizacije flore i faune rijeke Une i priobalnog pojasa (sa CD-om). Sisačko-moslavačka županija, Sisak. [in Croatian] 
European Environment Agency (2012) The impacts of invasive alien species in Europe. European Environment Agency Technical report No 16/2012, Copenhagen. http://www. eea.europa.eu/publications/impacts-of-invasive-alien-species/at_download/file [accessed at July 27th 2015]

Environmental Systems Research Institute (2009) Introduction to GIS Mapping and ESRI's ArcGIS Software. Environmental Systems Research Institute. http://www.library.yale. edu/MapColl/files/docs/Introduction\%20to\%20GIS\%20Mapping\%20and\%20ArcGIS.pdf [accessed at November 29th 2014]

Franić, D. (1900a) Zemljopisne iskrice iz jugo-zapadne Hrvatske. Glasnik Hrvatskoga naravoslovnog društva 11(1-6): 143-146. [in Croatian]

Franić, D. (1900b) Zemljopisne iskrice iz jugo-zapadne Hrvatske. Glasnik Hrvatskoga naravoslovnog društva 12(1-3): 169-171. [in Croatian]

Grarock, K., Tidemann, C. R., Wood, J. T. \& Lindenmayer, D. B. (2014) Are invasive species drivers of native species decline or passengers of habitat modification? A case study of the impact of the common myna (Acridotheres tristis) on Australian bird species. Austral Ecology 39(1): 106-114. http://dx.doi.org/10.1111/aec.12049

Gunn, J. (2004) Encyclopedia of caves and karst science. Taylor and Francis, New York, 1940 pp.

Habeković, D., Pažur, K. \& Popović, J. (1992) Ihtiofauna nekih ličkih tekućica [The ichthyofauna of some running waters of Lika]. Croatian Journal of Fisheries 47(1-2): 23-33. [in Croatian]

International Union for Conservation of Nature (2001) IUCN Red List Categories and Criteria. Version 3.1. IUCN Species Survival Commission. IUCN, Gland, Switzerland and Cambridge, UK, ii + 30 pp.

Jadan, M., Čož-Rakovac, R., Topić Popović, N. \& Strunjak-Perović, I. (2007) Presence of unexpected phylogenetic lineages of brown trout Salmo trutta L. in Gacka River, Croatia. Aquaculture Research 38: 1682-1685.

Jelić, D., Žutinić, P. \& Jelić, M. (2009) Značenje i karakteristike ihtiofaune rijeke Ilove (središnja Hrvatska) [Characteristics and new data of river Ilova ichthyofauna (central Croatia)]. Croatian Journal of Fisheries 67(2): 53-61. [in Croatian]

Jelić, D., Žutinić, P. \& Jelić, M. (2010) New data on ichthyofauna of river Česma (central Croatia). Croatian Journal of Fisheries 68(3): 95-104.

Jelić, M., Jelić, D. \& Žutinić, P. (2012) Fish fauna of the lower reaches of the river Drava and surrounding marshland habitats near Donji Miholjac (Eastern Croatia). Croatian Journal of Fisheries 70(4): 153-167.

Jelić, D. (2011) New data on distribution of Cottus gobio Linnaeus, 1758 in Croatia with special overview on Adriatic Basin. Croatian Journal of Fisheries 70(1): 1-8.

Jones, W. \& Oliver, M. (2009) Health check for habitats and species. The Natura 2000 Newsletter. European Commission, $66 \mathrm{pp}$.

Keller, R. P., Geist, J., Jeschke, J. M. \& Kühn, I. (2011) Invasive species in Europe: ecology, status, and policy. Environmental Sciences Europe 23: 23. http://dx.doi.org/10.1186/21904715-23-23

Kottelat, M. \& Freyhof, J. (2007) Handbook of European freshwater fishes. Kottelat, Crnol, Switzerland and Freyhof, Berlin, 646 pp.

K. P. (1968) Nasađivanje štuke u sliv rijeke Like. Croatian Journal of Fisheries 23(1): 25. [in Croatian]

Langhoffer, A. (1905) Popis riba, koje su prispjele narodnom zoološkom muzeju u Zagrebu do konca godine 1900. Glasnik Hrvatskoga naravoslovnog društva 16: 148-220. [in Croatian] 
Lukač Reberski, J., Marković, T. \& Nakić, Z. (2013) Definition of the river Gacka springs subcatchment areas on the basis of hydrogeological parameters. Geologica Croatica 66(1): 39-53. http://dx.doi.org/10.4154/GC.2013.04

Maitland, P. S. (2000) Guide to freshwater fish of Britain and Europe. Hamlyn, London, 272 pp.

Marković, G., Filipčıć, R. \& Vuk, R. (2000) Geografija Hrvatske. Znanje, Zagreb, 102 pp. [in Croatian]

McNeely, J. A., Money, H. A., Neville, L. E., Scchei, P. \& WaAge, J. K. (2001) A global strategy on invasive alien species. IUCN Gland, Switzerland, and Cambridge, UK, in collaboration with the Global Invasive Species Programme. Cambridge, UK, 62 pp.

Miočić-Stošić, J., Jelić, D., BAšić, T., Kovačević, M., PJevac, P., Žutinić, P., Sučić, I., Jelić, M. \& Novosel, L. (2012) Raznolikost ihtiofaune rijeke Zrmanje (južna Hrvatska) / Diversity of ichthyofauna of the river Zrmanja (southern Croatia). 11. Hrvatski biološki kongres s međunarodnim sudjelovanjem, 16-21. rujna 2012, Šibenik, Hrvatska (Zbornik sažetaka). 11th Croatian Biological Congress with International Participation 16th-21st September 2012, Šibenik, Croatia (Proceeding of abstracts).

Mrakovčić, M., Brigić, A., Buj, I., Ćaleta, M., Mustafić, P. \& Zanella, D. (2006) Crvena knjiga slatkovodnih riba Hrvatske. Ministarstvo kulture, Državni zavod za zaštitu prirode, Zagreb. [in Croatian]

Mrakovčić, M., MišEtić, S. \& Povž, M. (1995) Status of freshwater fish in Croatian Adriatic river systems. Biological Conservation 72(2): 179-185. http://dx.doi.org/10.1016/00063207(94)00080-A

Mustafić, P., Marčić, Z., Duplić, A., Mrakovčić, M., Ćaleta, M., Zanella, D., Buj, I., Podnar, M. \& Dolenec, Z. (2008) A new loach species of the genus Cobitis in Croatia. Folia Zoologica 57(1-2): 4-9.

Pavić, R. (1975) Geografija SR Hrvatske 4. Gorska Hrvatska. Školska knjiga, Zagreb. [in Croatian]

Pettorelli, N. (2013) The normalized difference vegetation index. Oxford University Press, New York, 224 pp.

PL. (1946) Novonaseljene ribe u rijeci Lici. Croatian Journal of Fisheries 1(3): 31. [in Croatian]

PolJaK, J. (1924) Velebit (Fauna Velebita). Priroda 14: 159-176. [in Croatian]

Povž, M. \& Sкет, B. (1990) Naše sladkovodne ribe [Our freshwater fish]. Mladinska knjiga, Ljubljana, 359 pp. [in Slovanian]

Ricciardi, A., Hoopes, M, F., Marchetti, M. P. \& Lockwood, J. L. (2013) Progress toward understanding the ecological impacts of nonnative species. Ecological Monographs 83: 263-282. http://dx.doi.org/10.1890/13-0183.1

Rodriguez, L. F. (2006) Can invasive species facilitate native species? Evidence of how, when, and why these impacts occur. Biological Invasions 8(4): 927-939. http://dx.doi. org/10.1007/s10530-005-5103-3

Rydén, L., Migula, P. \& Andersson, M. (2003) Environmental science: understanding, protecting and managing the environment in the Baltic Sea region. Baltic University Press, Uppsala, 824 pp.

Schlaepfer, M. A., Sherman, P. W., Blossey, B. \& Runge, M. C. (2005) Introduced species as evolutionary traps. Ecology Letters 8: 241-246. http://dx.doi.org/10.1111/j.14610248.2005.00730.x

Smith, K. G. \& DARwAll, W. R. T. (2006) The status and distribution of freshwater fish endemic to the Mediterranean Basin. IUCN, Gland, Switzerland and Cambridge, UK, 44 pp. 
Steindachner, F. (1866) Ichthyologische Notizen (II). Zur Flussfischfauna von Croatien (Phoxinellus croaticus n. sp.). Sitzungsber. Akademie der Wissenschaften in Wien, Mathematisch-Naturwissenschaftliche Klasse.

Strauss, S. Y., Lau, J. A. \& Carroll, S. P. (2006) Evolutionary responses of natives to introduced species: what do introductions tell us about natural communities? Ecology Letters 9: 357-374. http://dx.doi.org/10.1111/j.1461-0248.2005.00874.x

ŠRU “LikA" Gospić (2014) “O udrugi” \& “Riblje vrste”. ŠRU “Lika” Gospić. [in Croatian] http://www.sru-lika-gospic.com [accessed at May 20th 2014]

Takács, P., Bihari, P., Erós, T., Specziár, A., Szivák, I., Bíró, P. \& Csoma, E. (2014) Genetic heterogeneity reveals on-going speciation and cryptic taxonomic diversity of streamdwelling gudgeons (Teleostei, Cyprinidae) in the Middle Danubian hydrosystem (Hungary). PlosOne 9(5): e97278. http://dx.doi.org/10.1371/journal.pone.0097278

TrgovčEvić, L. (1905) Paraphoxinus Blkr. i Telestes Bonap. u vodama Like i Krbave. Nastavni vjesnik 14, Zagreb. [in Croatian]

Trgovčević, L. (1908) Prilog ihtiofauni ličkih potoka. Glasnik Hrvatskoga Naravoslovnoga Društva 20: 229-239. [in Croatian]

Trgovčević, L. (1932) Lički piori Paraphoxinus Blkr., Telestes Bonap., Phoxinus Agass. Pp. 73-74. In: Taler, Z. (ed.): Vode i ribe Jugoslavije. Zagreb. [in Croatian]

Vila-Gispert, A., Alcaraz, C. \& Garcia-Berthou, E. (2005) Life-history traits of invasive fish in small Mediterranean streams. Biological Invasions 7:107-116. http://dx.doi. org/10.1007/s10530-004-9640-y

Vuković, T. \& Ivanović, B. (1971) Slatkovodne ribe Jugoslavije. Zemaljski muzej BiH, Sarajevo. [in Serbian]

Whitehead, P. G., Battarbee, R. W., Crossman, J., Elliott, J. A., Wilby, R., Monteith, D. T. \& KERnAN, M. (2012) River and lake water quality: future trends. NERC/Centre for Ecology \& Hydrology. http://nora.nerc.ac.uk/17812 [accessed at January 21st 2015]

Zupančič, P., Mrakovčić, M., Marčić, Z., Naseka, A. M. \& Bogutskaya, N. G. (2010) Identity of Squalius (Actinopterygii, Cyprinidae) from Istra Peninsula in Croatia (Adriatic Sea basin). ZooKeys 53: 45-58. http://dx.doi.org/10.3897/zookeys.53.472

ŽGANEC, K. (2012) The effects of water diversion and climate change on hydrological alteration and temperature regime of karst rivers in central Croatia. Environmental Monitoring and Assessment 184(9): 5705-5723. http://dx.doi.org/10.1007/s10661-011-2375-1

Žutinić, P., Jelić, D., Jelić, M. \& Buj, I. (2014) A contribution to understanding the ecology of the large spot barbel - sexual dimorphism, growth and population structure of Barbus balcanicus (Actinopterygii; Cyprinidae) in Central Croatia. North-Western Journal of Zoology 10(1): 158-166.

Received March 2, 2015, accepted October 24, 2015, published May 6, 2016 


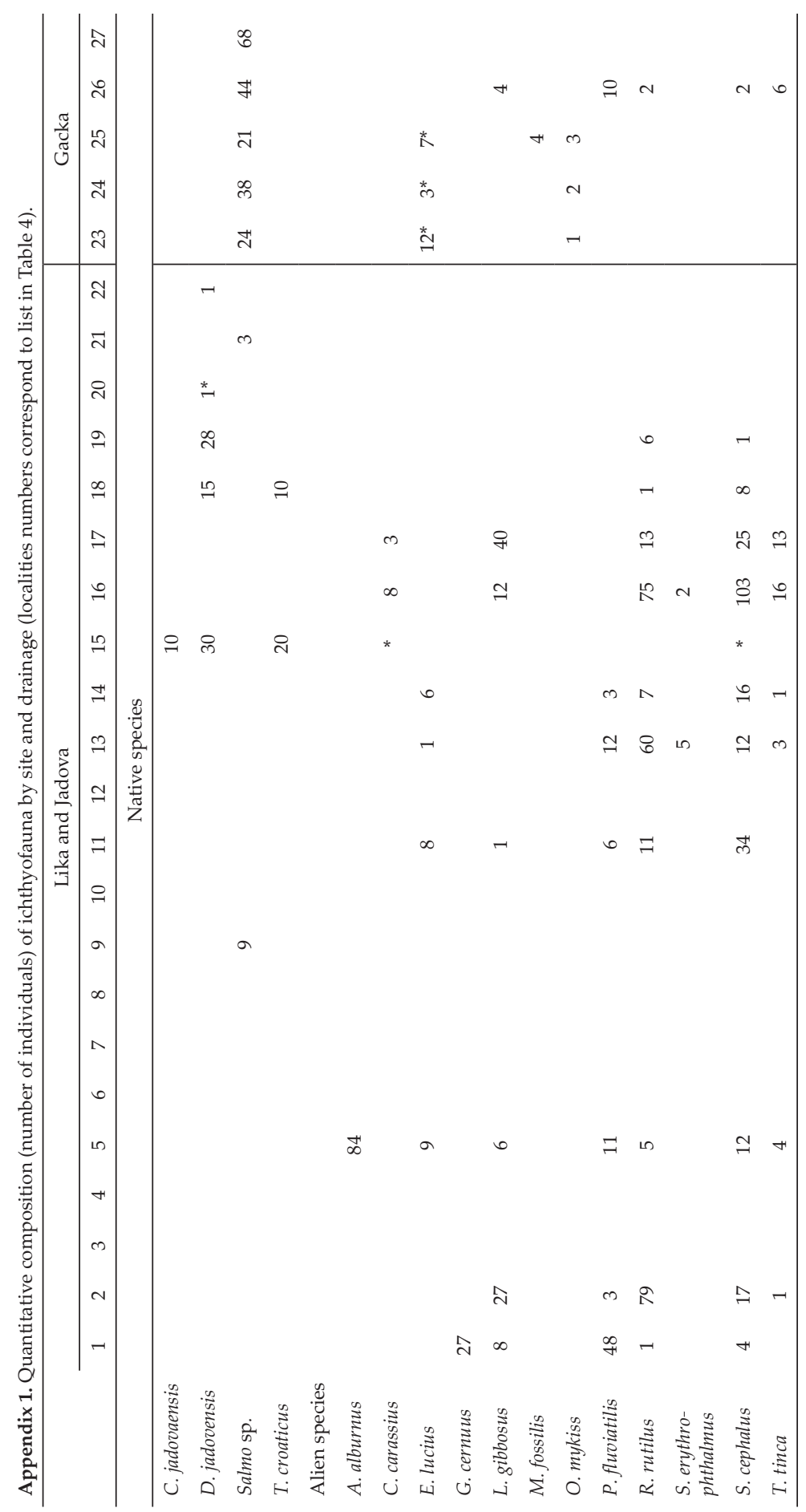




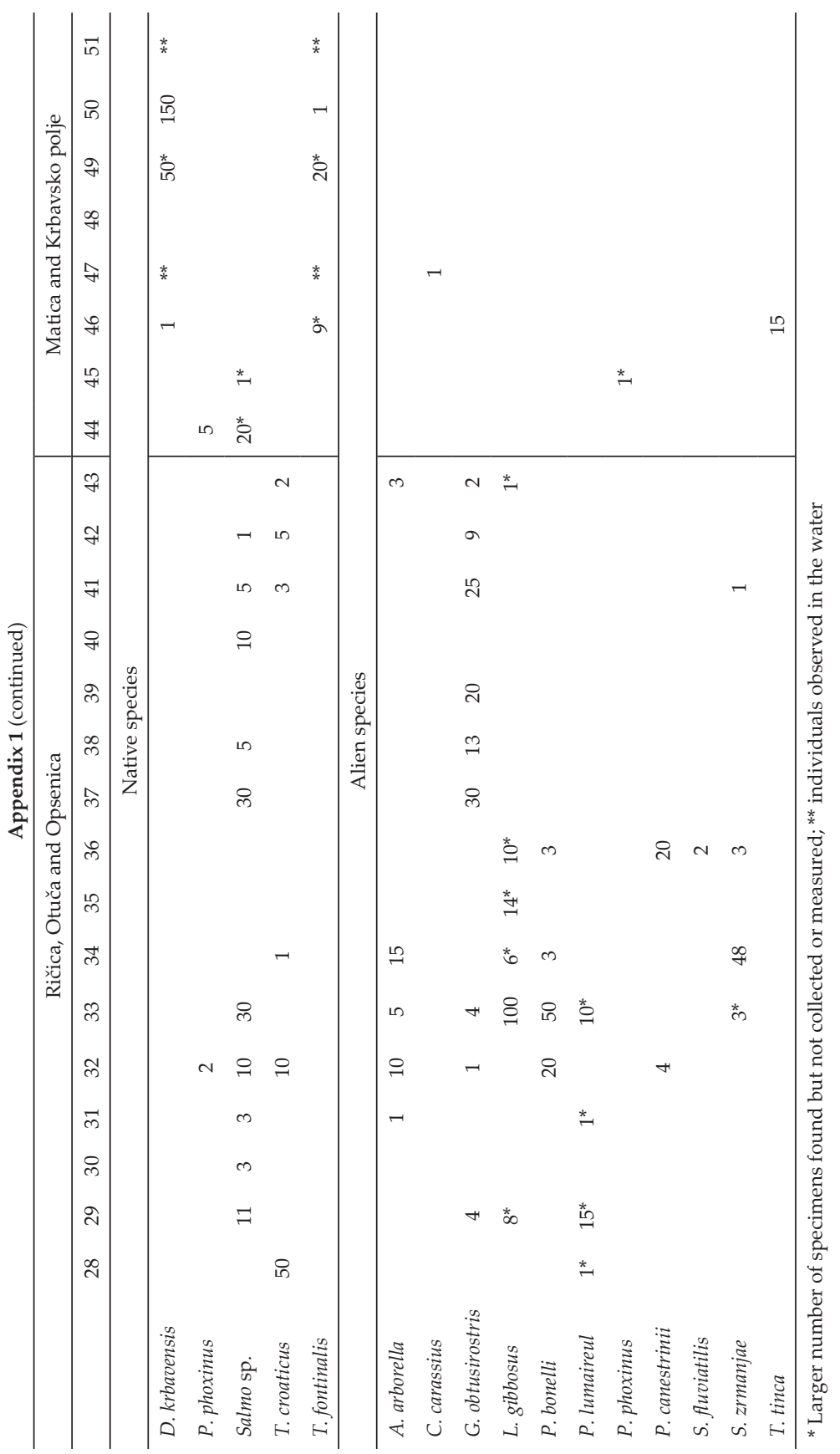

